\title{
THE INFLUENCE OF TREE INDUCE SUCTION ON SOIL SUCTION PROFILES
}

\author{
M.F. Ishak ${ }^{1}$, N. Ali ${ }^{2}$, A. Kassim ${ }^{3}$ \\ ${ }^{1}$ Faculty of Civil Engineering \& Earth Resources, University Malaysia Pahang, 26300 Kuantan, Pahang, Malaysia \\ ${ }^{2,3}$ Faculty of Civil Engineering, Universiti Teknologi Malaysia, 81310 Skudai, Johor, Malaysia, \\ fakhrurrazi@ump.edu.my,nazriali@utm.my,azmankassim@utm.my
}

\begin{abstract}
This study provided an investigation of active root tree zone located at the toe of the slope. This section of slope generated suction due to tree water uptake during dry season. A field monitoring set up program was carried out to collect matric suction data at slope with absent of a tree and with a tree located at toe of the slope. The installations of Jet-fill tensiometer and Gypsum blocks to measured matric suction were placed at vicinity of tree with certain depths and distances. The distribution in matric suction values and matric suction profiles responses to tree water uptake and rainfall were investigated. The decreased of soil matric suction after intense rainfall in this monitoring period as a function of an initial condition before the water uptake driven by active root tree substantially increased matric suction (low moisture content). Matric suction significantly increased at vicinity of tree trunk located at toe of slope compared to the slope without tree. This exploration provides the viewed of mature tree can significantly alter the suction distribution driven by transpiration in an unsaturated soil slope. It takes consideration by preserved mature tree can improved soil properties in geotechnical slope design.
\end{abstract}

Index Terms: active root zone, tree water uptake, field monitoring, unsaturated soil, matric suction

\section{INTRODUCTION}

The total water transpiration can then be assumed to be the same as the water uptake through the root zone. Therefore, soil suction that exert from water uptake by tree roots can significantly change the soil moisture near vicinity of the tree. In this study, matric suction generated by tree was measured and water uptake by plant root is treated as a sink term distribute in the active root zone is mainly considered. The tree has developed different adaptations and strategies to acquire water to transpire and photosynthesize (Nisbet 2005) such as: deep water uptake, stomata closure, water storage, etc. Hence, this transpiration water-uptake becomes one of the most important mechanisms influencing the water availability in soils (e.g. depletion of available water from soil).

From the previous researches were conducted, present of tree will affect the suction in soil. The water beneath the soil is being extract for the process of transpiration by the tree. Water uptake by tree root is influence by several factors such as species of tree, type of soil, wind speed and weather. Biddle (1983) has found the significant soil moisture contour varies by different tree type and not influence by soil clay type. Thus, it is found the pattern of soil moisture deficit has occur and may similar for different clay and the amount of clay shrinkage with the associated risk of structural damage will depend on the clay characteristics.
Apart from providing natural mechanical soil reinforcement, tree roots dissipate excess pore water pressure and produce sufficient matric suction to increase the shear strength of the surrounding soil. It is well recognised that vegetation has various mechanical and hydrological effects on ground stability. Most researcher ([8],[9],[14]) are attempts to quantify these effects have focused on the mechanical strengthening provided by the roots, but ignore the implications of evapotranspiration for the soil pore water pressure. However, the model was develop and application of a numerical model of water uptake in the vicinity of established trees was produced by [1] and set a new approached on hydrologic effect for the stability of slope. Also, [10] develop a mathematical model for the rate of root water uptake that considers ground conditions which highlighted the inter-related parameter of contribution to the development of conceptual evapotranspiration and root moisture uptake equilibrium model.

This paper present the results of matric suction monitored in an instruments place on slope with a tree located at toe and absent of a tree at study area of Faculty Electrical Engineering, University Technology Malaysia, Johor, Malaysia. The changes of matric suction due to tree induces suction was revealed in soil suction distribution profiles at various conditions from wet season (high rainfall) to dry season (prolonged no rainfall). 


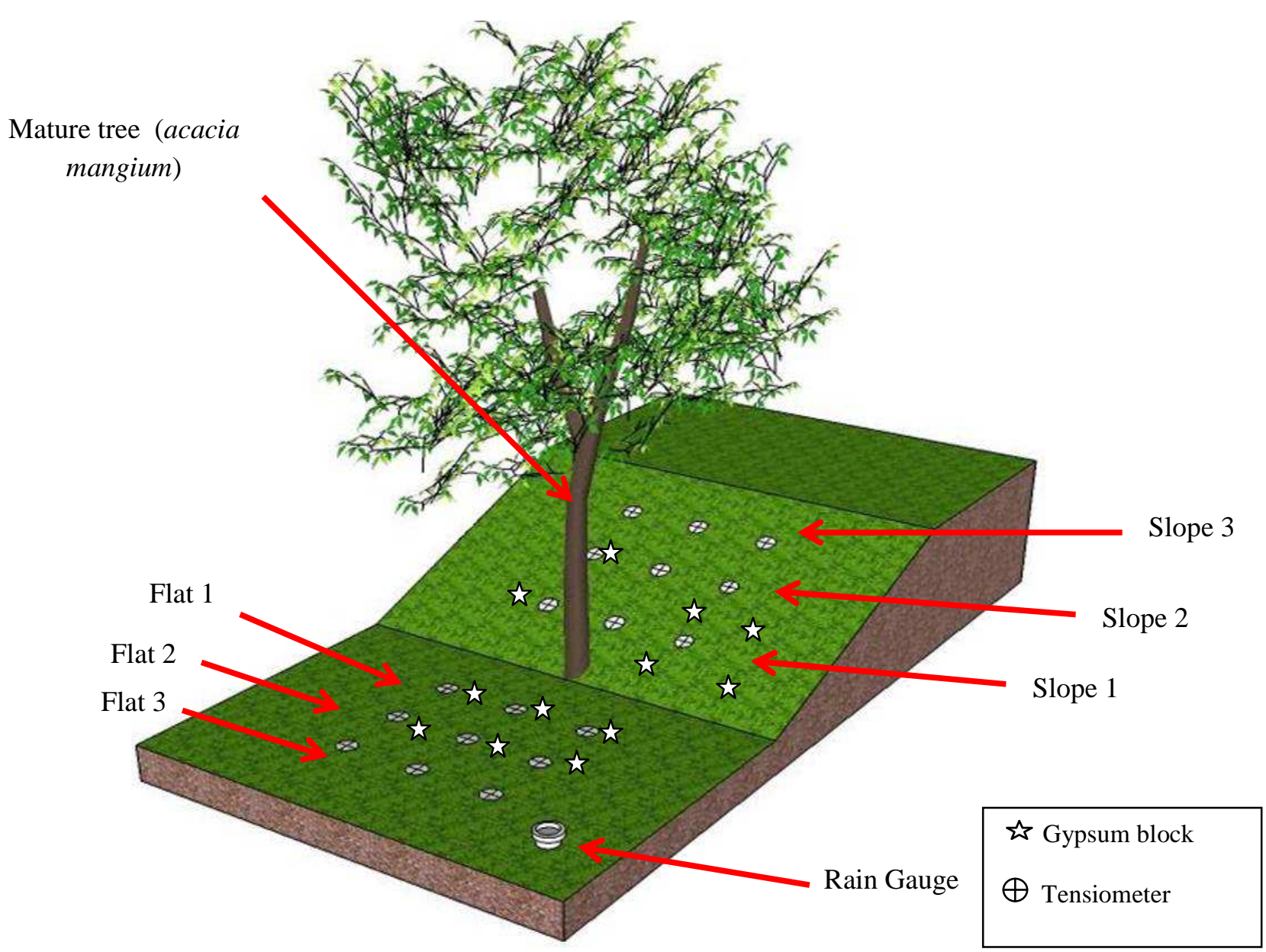

Fig -1: Acacia mangium tree located at the toe of slope with position of instrument (tensiometer, gypsum block \& raingauge)

\section{MATERIALS AND METHODS}

\subsection{Site Description}

The tree was located at toe of slope at Faculty of Electrical Engineering University, Technology Malaysia as showed in Figure 1. An area of the slope, approximately $80 \mathrm{~m}$ wide (measured across the slope) and 5m Height (measured down the slope) was considered to select for the installing instrumentation. A uniform slope with an inclination of approximately 310 with area consisted of horizontal crest.

\subsection{Field Instrumentation Monitoring Program}

To monitoring the soil matric suction changes in the slope due to acacia manggium tree, jet-fill tensiometers (Figure 2) were installed. Jet-fill tensiometer (Soilmoisture Equipment Corp. $\mathrm{CA}$ ) is used since it can measure directly the soil suction that range between $0 \mathrm{kPa}$ to $100 \mathrm{kPa}$. To measure the high suction beyond $100 \mathrm{kPa}$ up to $1000 \mathrm{kPa}$, the gypsum blocks (Delmhorst Instrument Co. Model 5KS-D1 G-Block) with a measuring capacity of $10 \mathrm{kPa}$ to $1500 \mathrm{kPa}$ was introduced for the measurement of high range of soil suction (Figure 3 ). The gypsum blocks and tensiometer were installed with same arrangement in this particular field instruments. Figure 1 show the locations and layout of instrument installed in the area. Each station consist of tensiometer and gypsum block namely as Station slope 1, Station slope 2 and Station slope 3 at distance of $1.0 \mathrm{~m}, 2.0 \mathrm{~m}$ and $4.0 \mathrm{~m}$ from tree and installed at depth $0.5 \mathrm{~m}, 1.0 \mathrm{~m}$ and $1.5 \mathrm{~m}$, respectively. That were consider as top, middle and bottom of the root zone, according to Biddle (1998) that find the active root zone has extend until a depth of $2 \mathrm{~m}$. 
The readings to measure the soil suction change and related to volumetric water content using a soil water characteristic curve were taken daily at 9:00 a.m. and 5:00 p.m. Since rain gauges were used in this study, rainfall data were monitored using a hyrologger (ISCO 675).

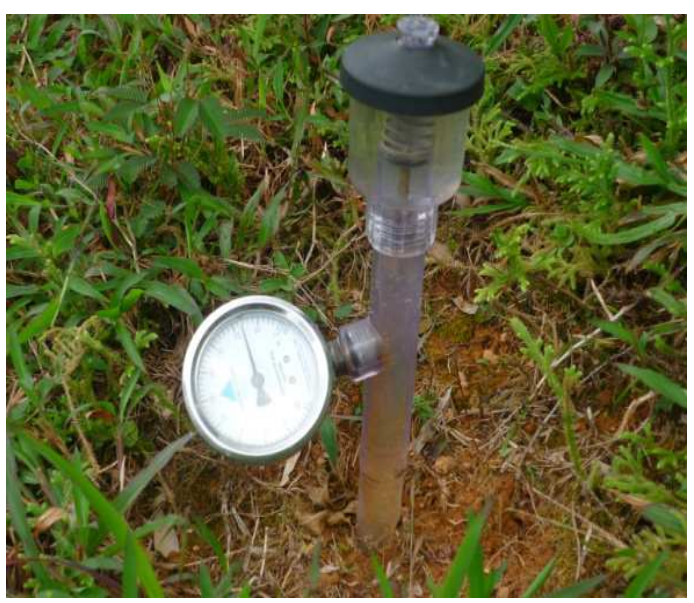

Fig -2: Tensiometer

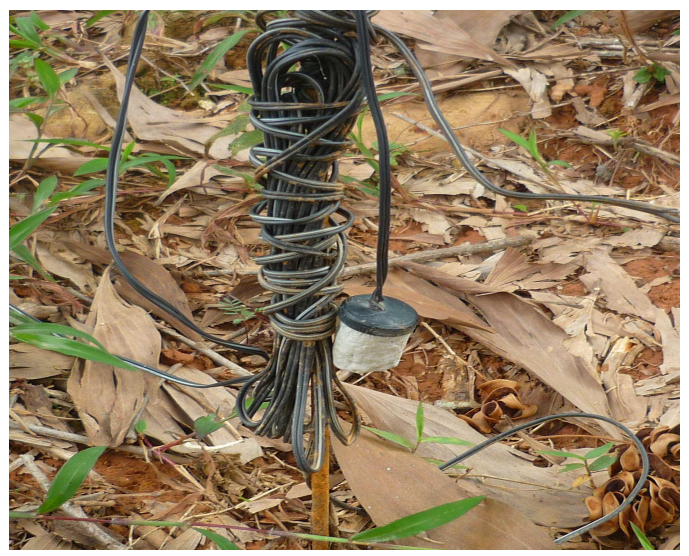

Fig -3: Gypsum block

\subsection{Soil Properties}

The disturbed and undisturbed soil samples were collected at the ground surface up to $1.5 \mathrm{~m}$ depth of the study area. A series of laboratory testing were conducted to determined soil properties, which can determine the soil type and geotechnical properties as presented in Table 1. The main physical index property of the soils investigated in this study was soil classification, which depends on several factors such as the Atterberg limits, specific gravity, particle size distribution (Figure 4), porosity and void ratio.
Table -1: The properties of the soil material in this study area

\begin{tabular}{|l|l|}
\hline Composition & Sandy SILT \\
\hline Gravel (\%) & 5.1 \\
\hline Sand (\%) & 20.9 \\
\hline Silt (\%) & 48.7 \\
\hline Clay (\%) & 25.3 \\
\hline Liquid Limit, LL (\%) & 71 \\
\hline Plastic Limit, PL (\%) & 39 \\
\hline Plasticity Index, PI (\%) & 32 \\
\hline $\begin{array}{l}\text { Specific Gravity (Gs) } \\
\text { Void Ratio (e) }\end{array}$ & 2.62 \\
\hline Porosity (n) & 1.44 \\
\hline Permeability (ksat (m/s)) & $4.1 \mathrm{x} 10-7$ \\
\hline $\begin{array}{l}\text { Effective Cohesion (c') } \\
(\phi b)\end{array}$ & 9 \\
\hline $\begin{array}{l}\text { Effective Friction Angle } \\
\text { Unsaturated Friction Angle }\end{array}$ & 23 \\
\hline
\end{tabular}

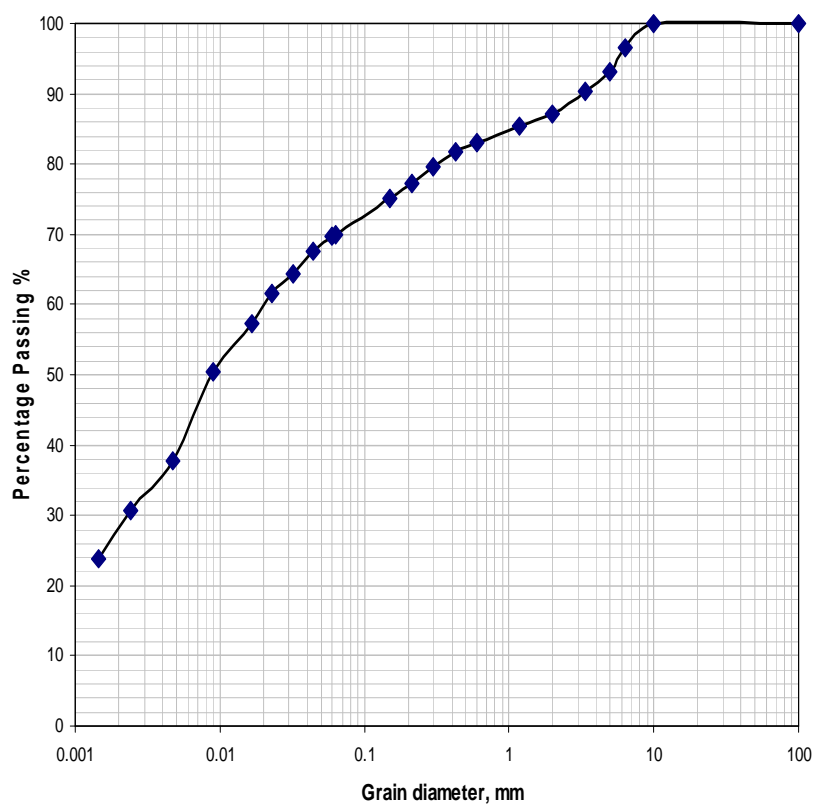

Fig -4: Particle size distribution curve of sandy SILT 


\subsection{Soil Water Characteristic Curve (SWCC)}

The soil-water characteristic curves (SWCC) of residual soils at Faculty of Electrical Engineering Universiti Teknologi Malaysia are shown in Figure 5. The SWCC for low suctions (less than $1500 \mathrm{kPa}$ ) was determined by fitting the average value from a series of pressure plate extractor tests. Based on this SWCC, the parameters such as saturated volumetric water content ( $\square \mathrm{s}$ ), air entry value (Aev) and residual volumetric water content ( $\square \mathrm{r}$ ) of the soils can be identified and shown in figure 5.

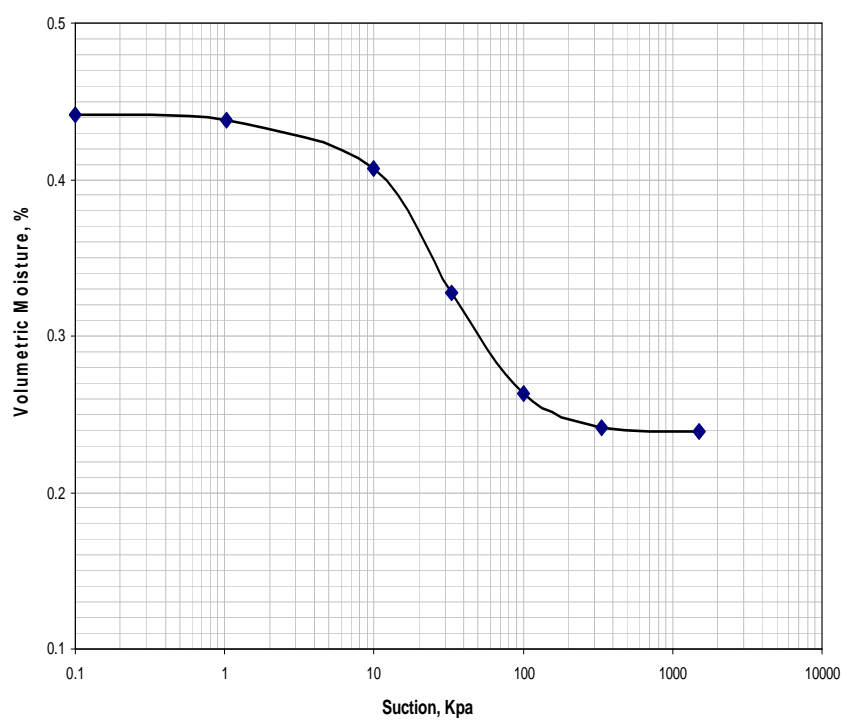

Fig -5: Soil Water Characteristic Curve (SWCC)

\section{FIELD MONITORING RESULT}

Field measurements results are presented for 20th December 2011 to 20th January 2012. This period falls under the wet season northeast monsoon blows from east part across peninsular Malaysia from November, 2011 to dry season in March, 2012 (Meteorology Department Malaysia). The changes in matric suction, matric suction profiles influence by tree water uptake and response to rainfall within vicinity of tree shows in soil suction profiles are investigated.

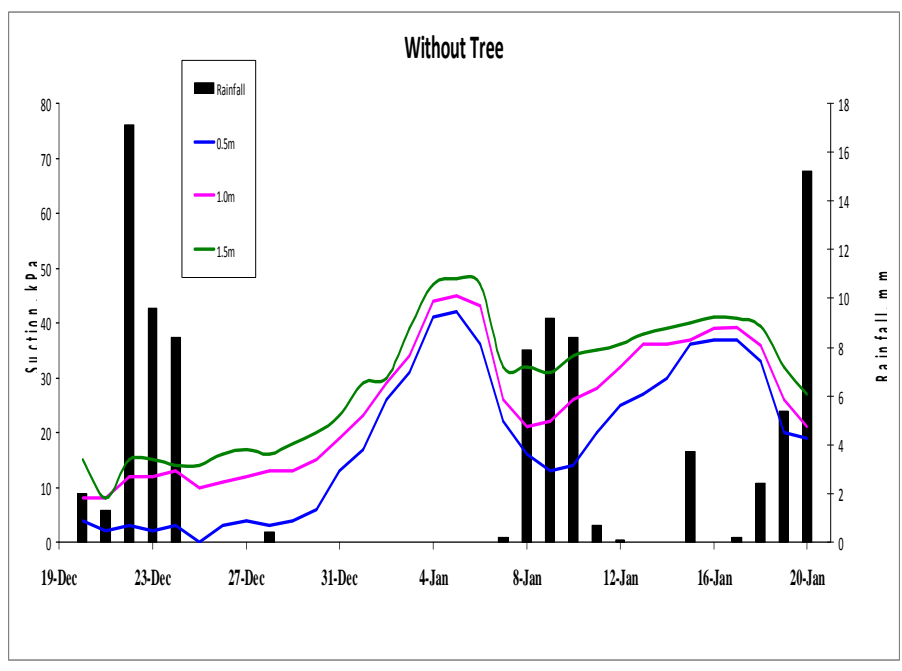

Fig -6: Field matric suction with depth respond to rainfall distribution at slope without tree

Figure 6 shows field suction envelopes measured at $0.5 \mathrm{~m}$, $1.0 \mathrm{~m}$ and $1.5 \mathrm{~m}$ without tree at the toe of the slope and can be a function as control matric suction in soil. During this field monitoring period, the suction at $1.0 \mathrm{~m}$ and $1.5 \mathrm{~m}$ have never reached $0 \mathrm{kPa}$ (suction disappeared). However, the suction at $0.5 \mathrm{~m}$ depth deceased to $0 \mathrm{kPa}$ after several of long and intense rainfall event.

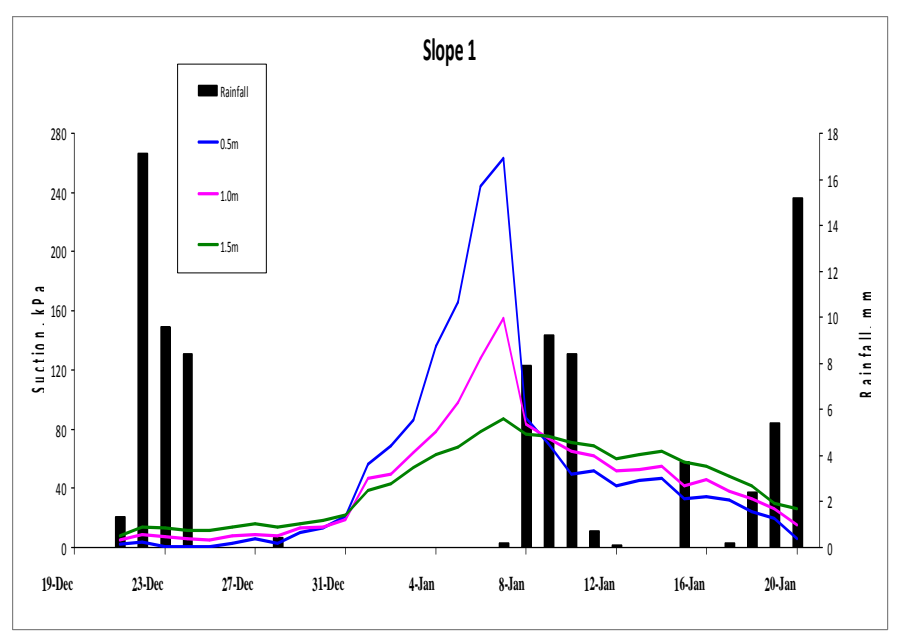



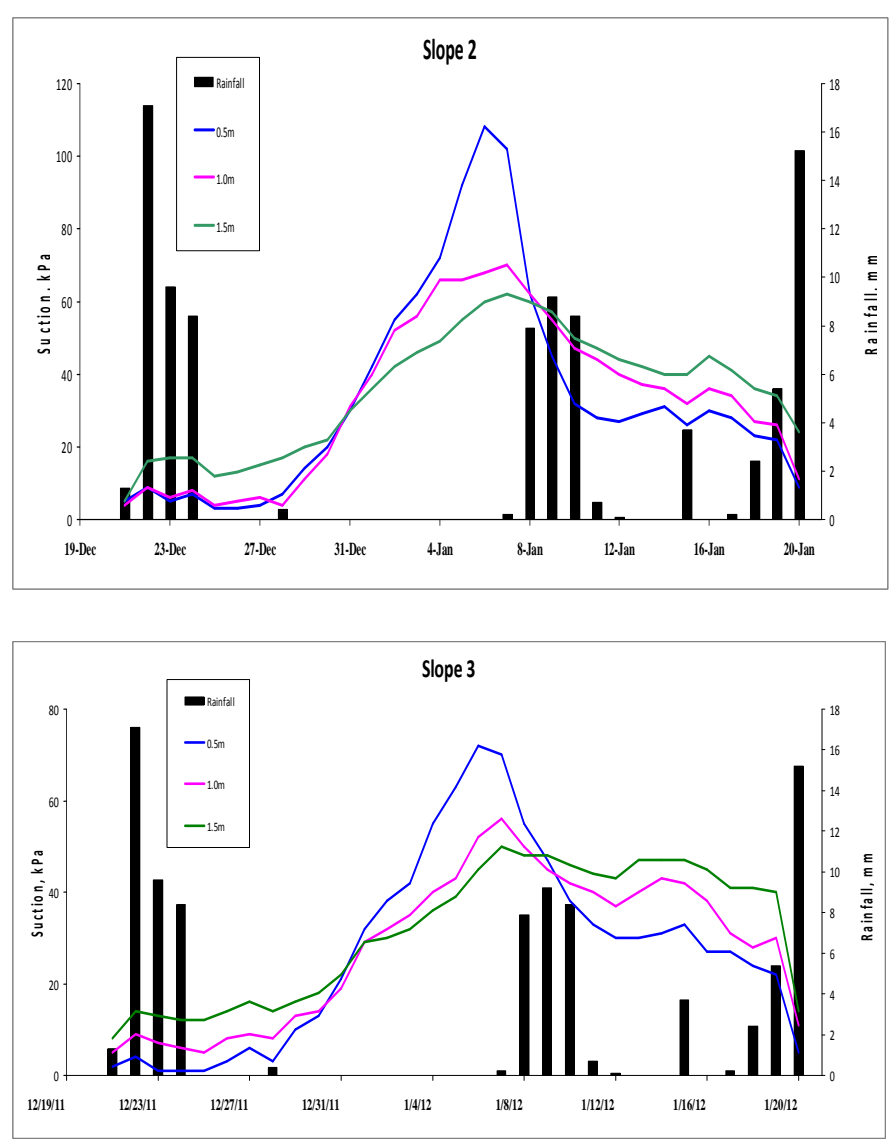

Fig -7: Field matric suction with depth respond to rainfall distribution at Station slope 1, 2 and 3

Field monitoring data collections from the slope name as Station slope 1, 2 and 3 were applied for analyses of this study. Figure 7 shows the matric suction were measured by combination of tensiometer and gypsum with depth and daily rainfall data. The three lines shown on the graph represents readings from the instruments (matric suction) at depth as indicated in the legend. The bar graph represents the rainfall data and shows that rainfall occurred during this period of monitoring.

The suction variation was considerably large, on 6 January 2012 after twelve day without rainfall, for Station slope 1 the matric suction at $0.5 \mathrm{~m}$ reached value approximately $280 \mathrm{kPa}$, while the change in the matric suction was approximately $278 \mathrm{kPa}$.

Field monitoring data shows in figure 7 were plotted, matric suction with respect to depth and rainfall were allow easier configuration and comparison between the field monitoring data Station slope and without tree. However, during this field monitoring, the suction at $0.5 \mathrm{~m}, 1.0 \mathrm{~m}$ and $1.5 \mathrm{~m}$ have never reached $0 \mathrm{kPa}$ (suction disappeared) at Station slope despite received several long and intense rainfall event.

\section{MATRIC SUCTION RESPOND DUE TO TREE} WATER UPTAKE ANALYSIS

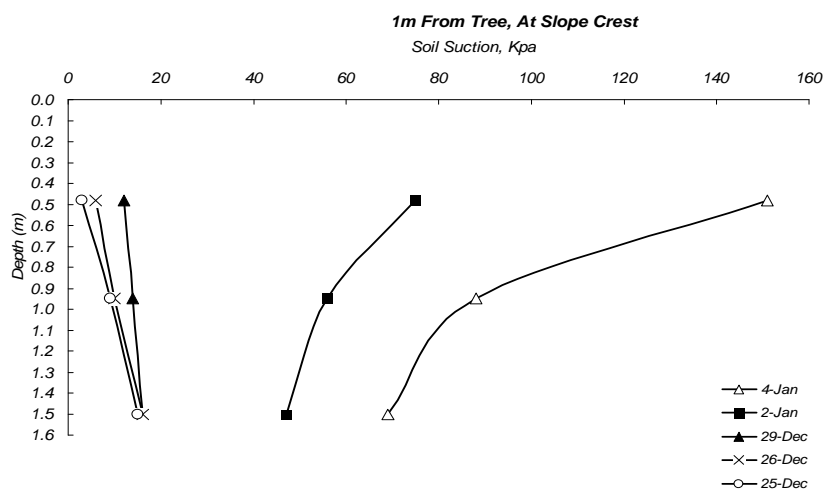

Fig -9: Field matric suction profile directly at $1 \mathrm{~m}$ from tree (Station slope1).

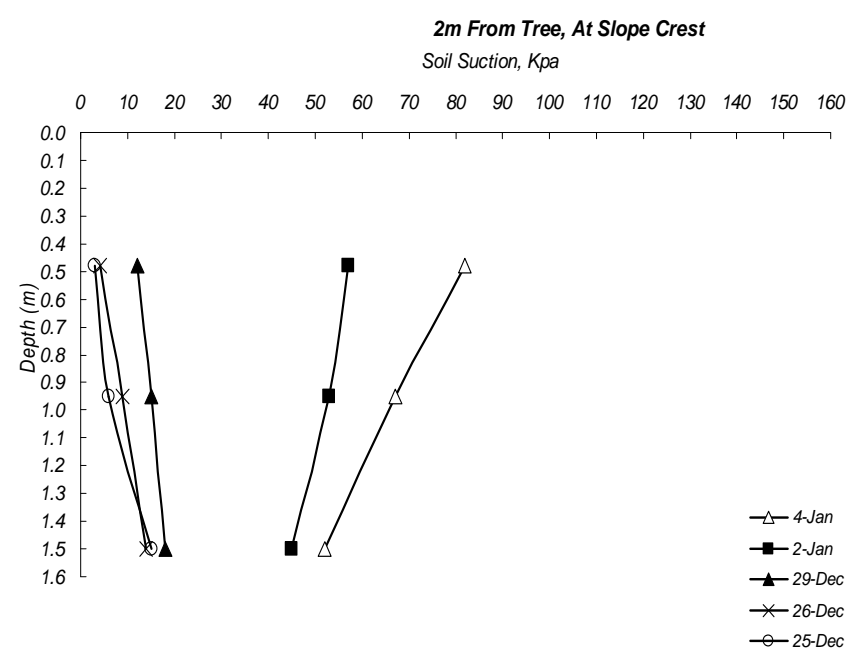

Fig -10: Field matric suction profile directly at $2 \mathrm{~m}$ from tree (Station slope 2).

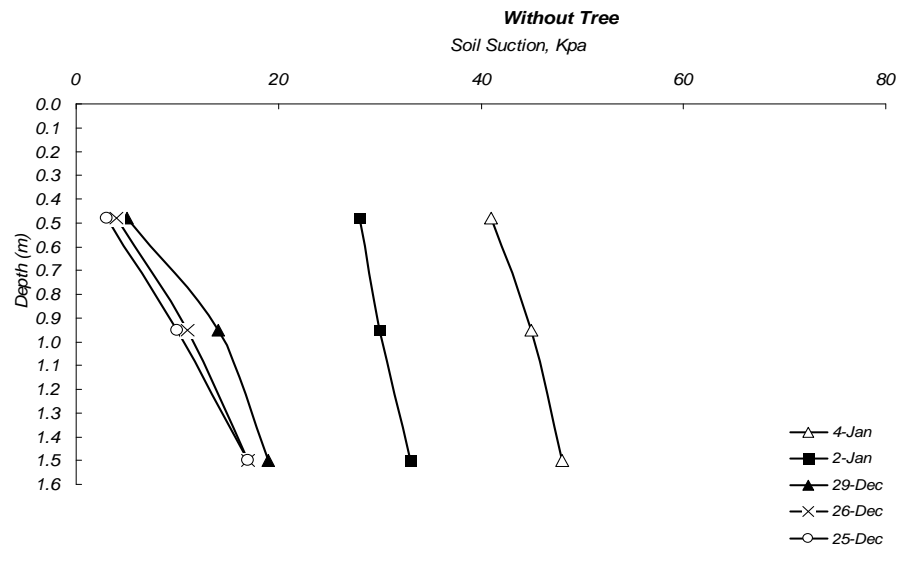

Fig -11: Field matric suction profile at slope without tree. 
Figure 9 shows the corresponding suction profile result on days; 26th December 2011, 27th December 2011, 29th December 2011, 2nd January 2012 and 4th January 2012. The largest changes in matric suction occur at $0.5 \mathrm{~m}$ depth, where the water uptake by tree roots is at its maximum. At this location the matric suction increase significantly from an initial value $3 \mathrm{kPa}$ to $151 \mathrm{kPa}$, yielding a $148 \mathrm{kPa}$ change in matric suction. At the lower part of the profile at $1.5 \mathrm{~m}$ the matric suction has change by only $37 \mathrm{kPa}$ after $10 \mathrm{day}$ of transpiration.

Figure 10 presents the matric suction profile at distance of $2.0 \mathrm{~m}$ from the tree slope station (Station slope 2). This profile shows a marginally reduced impact of the water uptake or transpiration influence occurring at slope. The highest matric suction generated at this location is now approximately $82 \mathrm{kPa}$. Figure 11 show the matric suction profile at toe of the slope without tree. These profiles reveal the maximum yielding of matric suction at $0.5 \mathrm{~m}$ was approximately $38 \mathrm{kPa}$.

\section{CONCLUSIONS}

A field monitoring program was established to quantify the hydrological impact on slope by preserved mature tree at toe of slope. Field monitoring were measured at various condition of weather and found significant changes in matric suction. Data were collected on several places proximity of tree at the toe of slope and slope without tree. The analyses of matric suction results with respect to water uptake base solely on single mature tree affected to residual soil of sandy SILT on the slope.

During the period of no rainfall, slope with preserved of tree increased significantly compared to slope without tree. These owing by tree water uptake driven by active root tree zone that generate suction through the soil. Soil suction was generally greater at $1 \mathrm{~m}$ and decrease gradually at $2 \mathrm{~m}$ and $4 \mathrm{~m}$ from tree trunk. These contributed by distribution of active root concentrated particularly at vicinity of tree truck and at shallow depth $(<0.5 \mathrm{~m})$. Therefore, by preserving mature tree to accelerate of matric suction was an effective method to increase suction. In related with this, tree water uptake (transpiration) from root activity of tree will create dry conditions that eventually occurred at proximity of tree trunk with depth up to $1.5 \mathrm{~m}$ below the surface.

\section{REFERENCES}

[1]. N. Ali, S.W. Rees (2008). Preliminary analysis of treeinduced suctions on slope stability. Proceedings Of The First European Conference On Unsaturated Soils, 2008, Durham, United Kingdom. CRC Press, Taylor \& Francis Group, London, Uk. pp. 811-816

[2]. Alva AK, Om Prakash, Ali Fares, Arthur G. Hornsby (1999). Distribution of rainfall and soil moisture content in the soil profile under citrus tree canopy and at the dripline. Irrig Sci (1999), Springer-Verlag 1999, 18: pp. 109-115
[3]. Azman Kassim, Nurly Gofar, Lee Min Lee, Harianto Rahardjo (2012). Modelling of suction distributions in an unsaturated heterogeneous residual soil slope. Engineering Geology 131-132 (2012), pp. 70-82

[4]. Biddle P. G. (1983). Pattern of soil drying and moisture deficit in the vicinity of trees on clay soils. Ge'Otechnique, 33, No. 2, pp. 107-126

[5]. Biddle, P.G. (1998). Tree root damage to buildings. Willowmead Publishing Ltd, Ickleton Road, Wantage

[6]. Blight, G.E. (2003). The vadose zone soil water balance and transpiration rates of vegetation. Essex. Geotechnique, No.1, pp. 55-64

[7]. Dombro, D.B. (2009). Acacia Mangium: Amazonia Reforestation's miracle tree. Planeta Verde Reforestación S.A., An e-book for tropical tree investor.

[8]. Greenway DR (1987). Vegetation and slope stability. In: Anderson MG, Richards KS (eds) Slope stability. Wiley, Chichester, pp. 187-230

[9]. Greenwood, J.R. (2006). SLIP4EX-A program for routine slope stability analysis to include the effects of vegetation, reinforcement and hydrological changes. Geotechnical and Geological Engineering, 24: pp. 449-465

[10]. Indraratna, B., Fatahi, B., Khabbaz, H., (2006). Numerical analysismof Matric Suction Effects of Tree Roots. Geotech. Eng., Proc. Inst. Civil Eng. 159, pp. 77-90

[11]. Koumanov K.S., Hopmans J.W., Schwankl L.J., Andreu L., Tuli A., (1997). Application Efficiency Of Micro-Sprinkler Irrigation Of Almond Trees. Agricultural Water Management 34 (1997), pp. 247-263

[12]. Lee Min Lee, Nurly Gofar, Harianto Rahardjo (2009). A simple model for preliminary evalution of rainfall-induce slope instability. Engineering Geology 108, pp. 272-285

[13]. Lim, T.T., Rahardjo, H., Chang, M.F. and Fredlund, D.G. (1996) Effect of Rainfall on Matric Suctions in a Residual Soil Slope. Canadian Geotechnical Journal. 33(4): pp. $618-628$

[14]. Marie Genet, Alexia Stokes, Thierry Fourcaud, Joanne E. Norris, (2009). The Influence Of Plant Diversity On Slope Stability In A Moist Evergreen Deciduous Forest. Journal Ecological Engineering 36 (2010), pp. 265-275

[15]. Mcinnes, D.B., (1986). Drying effect of different verge planted tree species on urban roads. In: 13 ARRB and 5th REAAA Conference, pp. 54-66

[16]. Nisbet, T. (2005). Forestry:Water Use by Trees. Conference of European Water Framework Directive 2000. Planeta Verde Reforestacion S.A ,UK,USA. pp. 1-3

[17]. Simon, A. \& Collison, A.J. 2002. Quantifying the mechanical and hydrologic effects of Riparian vegetation on stream-bank stability. Earth Surface Processes and Landforms, 27: pp. 527-546

[18]. Stephanie Glendinning, Fleur Loveridge, Ruth Elizabeth Starr-Keddle, M. Fraser Bransby, Paul N. Hughes, (2009). Role of vegetation in sustainability of infrastructure slopes. Geotech.Eng., Proc. Inst. Civil Eng. 162, pp. 101-110

[19]. S.W. Rees, N. Ali, (2012). Tree Induced Soil Suction And Slope Stability. Geomechanics and Geoengineering: An 
International Journal. Taylor \& Francis Group, London, Uk. Vol. 7, No. 2, pp. 103-113

\section{BIOGRAPHIES}

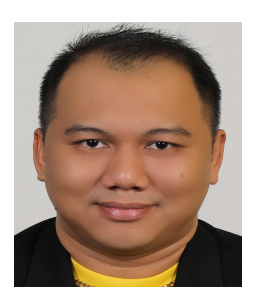

Mohd Fakhrurrazi Ishak started career at University Malaysia Pahang (UMP) as a lecturer, in January 2007. He actively in research area of slope failure, slope stabilization using bio-engineering

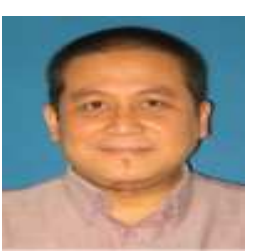

research area.
I have been attached with Department of Geotechnics and Transportation, Faculty of civil Engineering in Universiti Teknologi Malaysia (UTM) since 1999.

I specialize in geotechnical engineering numerical simulation and unsaturated soil 